\title{
HUBUNGAN KELEBIHAN BERAT BADAN TERHADAP TINGKAT RISIKO DIABETES MELLITUS TIPE II PADA MAHASISWA KELAS PROGRAM KHUSUS JURUSAN KEPERAWATAN DAN KEBIDANAN POLTEKKES KEMENKES PALANGKA RAYA
}

\author{
Relationship Between Overweight and Risk Level of Diabetes Mellitus Type II in Students of Specific Class \\ Programs for Nursing and Midwifes in Poltekkes Kemenkes Palangka Raya \\ ${ }^{1}$ *Berthiana, ${ }^{2}$ Mimin Lestari, ${ }^{3}$ Dian Ana Mutriqah \\ ${ }^{1}$ Program Studi D-IV Keperawatan Poltekkes Kemenkes Palangka Raya, Jl. G. Obos No. 30, 32, Palangka Raya, Indonesia \\ ${ }^{2}$ Program Studi D-IV Keperawatan Poltekkes Kemenkes Palangka Raya, Jl. G. Obos No. 30, 32, Palangka Raya, Indonesia \\ ${ }^{3}$ Program Studi D-IV Keperawatan Poltekkes Kemenkes Palangka Raya, Jl. G. Obos No. 30, 32, Palangka Raya, Indonesia \\ *e-mail : meworera8@gmail.com
}

\begin{abstract}
ABSTRAK
Dunia kini didiami oleh 171 juta penderita DM dan akan meningkat dua kali lipat, perkiraan 366 juta pada tahun 2030. Obesitas (kegemukan) merupakan faktor risiko DM tipe II. Dari hasil survei dan pengamatan peneliti di Poltekkes Palangka Raya terlihat beberapa mahasiswa kelas program khusus masuk dalam kategori berat badan lebih dan obesitas. Tujuan penelitian ini adalah untuk mengetahui hubungan kelebihan berat badan terhadap tingkat risiko DM tipe II pada mahasiswa kelas program khusus jurusan keperawatan dan kebidanan di Poltekkes Palangka Raya. Penelitian kuantitatif dengan studi korelasional dan desain penelitian menggunakan pendekatan cross-sectional. Terdapat hubungan yang signifikan antara kelebihan berat badan terhadap tingkat risiko DM tipe II berdasarkan analisa data uji chi-square, didapatkan nilai $\mathrm{p}$-value $=$ 0,077. Ada hubungan antara kelebihan berat badan berdasarkan indeks massa tubuh terhadap tingkat risiko DM tipe II.
\end{abstract}

Kata kunci : Diabetes melitus tipe II, risiko, obesitas, kelebihan berat badan

\section{ABSTRACT}

The world is now inhabited by 171 million people with Diabetes Mellitus (DM) and will double, an estimated 366 million by 2030. Obesity is a risk factor for type II DM. From the results of surveys and observations of researchers at the Palangka Raya Polytechnic, it was seen that some special program class students fall into the category of overweight and obese. This research aims to find out the relationship between overweight and the risk level of type II diabetes melitus in class students specialized in nursing and midwifery courses at Palangka Raya Polytechnic. A quantitative study with correlational studies and research design using a cross-sectional approach. There is a significant relationship between overweight to the risk level of type II DM based on the analysis of chi-square test data, obtained p-value $=0.077$. There was a relationship between excess body weight based on body mass index on the risk level of type II DM.

Keyword: diabetes mellitus type II, risk, obesity, overweight

\section{PENDAHULUAN}

Diabetes melitus (DM) merupakan penyakit yang disebabkan oleh gangguan metabolisme yang terjadi pada organ pankreas yang ditandai dengan peningkatan gula darah atau sering disebut dengan kondisi hiperglikemia yang disebabkan karena menurunnya jumlah insulin dari pankreas (ADA, 2012). Penyakit DM secara umum diakibatkan oleh konsumsi makanan yang tidak terkontrol atau sebagai efek samping dari pemakaian obat-obatan tertentu. Selain itu, DM disebabkan oleh tidak cukupnya hormon insulin yang dihasilkan pankreas untuk menetralkan gula darah dalam tubuh (Susilo, et al., 2011).

Kebanyakan individu, diabetes melitus tipe II berkaitan dengan kegemukan. Selain itu, kecenderungan pengaruh genetik, yang menentukan kemungkinan individu mengidap penyakit ini, cukup kuat. Diperkirakan bahwa terdapat sifat genetik yang belum teridentifikasi yang menyebabkan pankreas mengeluarkan insulin yang berbeda, atau menyebabkan reseptor insulin atau perantara kedua 
tidak dapat berespon secara adekuat terhadap insulin. (Corwin, et al., 2009).

Prevalensi Diabetes melitus yang mengalami peningkatan kejadian akan berdampak pada peningkatan jumlah penderita dan kejadian kematian yang disebabkan karena penyakit DM dan komplikasi dari DM itu sendiri. Menurut WHO (World Health Organization), dunia kini didiami oleh 171 juta penderita.

Di kota Palangka Raya pada tahun 2017, terdapat 1.557 kasus obesitas atau 39,18\% dari 3.974 orang yang diukur berat badannya di puskesmas (dalam dan luar gedung). Dimana obesitas pada perempuan sebesar $1.312(84,3 \%)$ dan laki-laki sebesar 245 (15,7 \%). Angka tersebut belum mewakili proporsi gender penyandang obesitas karena yang dilakukan pengukuran lebih banyak pada perempuan $(77,5 \%)$ dan laki-laki $(22,5 \%)$ (Profil Kesehatan Kota Palangka Raya, 2017).

Tingkat risiko DM tipe II akan meningkat seiring dengan peningkatan BMI pada penderita dewasa. Semakin tinggi BMI, maka angka terkena DM tipe II pun semakin besar. Artinya, orang yang mengalami kegemukan cenderung akan terkena DM tipe II (Susilo, et al., 2011).

Penelitian Fathurohman (2015) yang berjudul penilaian tingkat risiko dan faktor-faktor yang berhubungan dengan risiko diabetes melitus tipe $2 \mathrm{di}$ buaran Serpong, Hasil analisis hubungan antara IMT (Indeks Massa Tubuh) dengan tingkat risiko DM tipe 2 diperoleh hubungan yang bermakna antara IMT dan tingkat risiko DM tipe 2, orang dengan berat badan berlebih, obesitas derajat I, obesitas derajat II, dan obesitas derajat III memiliki risiko menderita DM tipe 2 dibandingkan dengan orang yang IMT nya normal secara berurutan adalah 1,5 kali, 2,5 kali, 3,6 kali, dan 5,1kali. Mekanisme yang mendasari lebih tingginya risiko DM tipe 2 pada individu dengan obesitas adalah karena pada keadaan obesitas terjadi peningkatan asam lemak, penumpukan lipid intra sel, dan pembentukan sitokin oleh adiposity yang menyebabkan kerusakan fungsi insulin. Pada keadaan obesitas juga terjadi proses inflamasi akibat peningkatan sitokin proinflamasi dan infiltrasi makrofag disertai adanya induksi respon stres yang dapat menyebabkan resistensi insulin.
Dari hasil survei dan pengamatan peneliti di Poltekkes Palangka Raya terlihat beberapa mahasiswa RPL dengan berat badan lebih dan terlihat beberapa mahasiswa kebidanan program khusus yang ada di Poltekkes Palangka Raya masuk dalam kategori obesitas. Rutinitas pekerjaan yang padat dan aktivitas yang kurang untuk berolahraga secara rutin setiap minggu menjadi salah satu penyebab kegemukan, dan kegemukan itu sendiri merupakan salah satu dari beberapa faktor risiko DM tipe II. Melalui wawancara mengenai faktor risiko DM tipe II, dengan salah satu mahasiswa kelas program khusus di Poletekkes Palangka Raya yang masuk dalam kategori berat badan lebih, mengatakan bahwa untuk aktivitas yang dilakukan sehari-hari tergolong ringan seperti pekerjaan rumah menyapu, kemudian aktivitas olahraga tidak rutin dilakukan setiap minggu hanya bila ada waktu luang olahraga seperti senam aerobic, namun untuk kebiasaan konsumsi dari buah dan sayur jarang diterapkan, dan untuk riwayat dari keturunan keluarga dengan penyakit DM tidak ada. Menurut hasil pengamatan dan wawancara yang dilakukan peneliti serta dari uraian di atas maka, peneliti tertarik untuk mengangkat judul "hubungan kelebihan berat badan terhadap tingkat risiko DM tipe II pada mahasiswa kelas program khusus jurusan keperawatan dan kebidanan di Poltekkes Palangka Raya".

\section{METODE PENELITIAN}

Penelitian kuantitatif dalam penelitian ini adalah dengan studi korelasional dan desain penelitian menggunakan pendekatan crosssectional. Peneliti melibatkan dua variabel dalam penelitian ini yaitu hubungan kelebihan berat badan terhadap tingkat risiko DM tipe II pada mahasiswa kelas khusus jurusan keperawatan dan kebidanan di Poltekkes Palangka Raya.

Penelitian ini dilakukan di Poltekkes Palangka Raya Kalimantan Tengah dengan alasan peneliti melihat fenomena yang ada wilayah tersebut terdapat beberapa mahasiswa program kelas khusus terlihat masuk dalam kategori BB lebih serta beberapa mahasiswa kelas khusus juga masuk dalam kategori obesitas. Waktu 
pengumpulan data dalam penelitian dilaksanakan pada bulan Maret-April tahun 2019.

Populasi dalam penelitian ini adalah seluruh mahasiswa kelas program khusus jurusan keperawatan dan kebidanan yang berjumlah 250 orang. Sampel yang digunakan peneliti adalah mahasiswa kelas khusus jurusan keperawatan dan kebidanan dengan berat badan lebih yang ada dilokasi penelitian Poltekkes Palangka Raya. Teknik yang digunakan peneliti untuk mengambil sampel adalah purposive sampling. Besar sampel yang diperlukan dalam penelitian ini berdasarkan rumus Lemeshow, et al. (1997) untuk uji hipotesis beda proporsi dua sisi (two tail). Jumlah sampel tersebut dikalikan dua untuk mendapatkan jumlah sampel pada dua proporsi sehingga minimal sampel yang dibutuhkan menjadi sebanyak 62 ditambahkan dengan $10 \%$ perkiraan drop uot sehingga total 68 sampel.

Instrumen yang digunakan dalam penelitian ini adalah alat ukur tinggi dan berat bedan serta kuesioner baku yaitu (FINDRISC) Finnish Diabetic Risk Score terdiri dari 8 item, mencakup usia, indeks massa tubuh (IMT), lingkar perut, riwayat penggunaan obat darah tinggi, riwayat gula darah tinggi, riwayat DM di keluarga, konsumsi sayur dan buah harian, dan aktivitas fisik.

\section{HASIL DAN PEMBAHASAN}

Tabel 1. Distribusi frekuensi karakteristik responden

\begin{tabular}{llcc}
\hline & Karakteristik & F & \% \\
\hline \multirow{4}{*}{ Usia } & $24-30$ tahun & 8 & $11,8 \%$ \\
\cline { 2 - 4 } & $31-40$ tahun & 21 & $30,9 \%$ \\
\cline { 2 - 4 } & 41-50 tahun & 27 & $39,7 \%$ \\
\hline \multirow{2}{*}{$\begin{array}{l}\text { Jenis } \\
\text { kelamin }\end{array}$} & Laki-laki & 12 & $17,6 \%$ \\
\hline \multirow{4}{*}{ Pekerjaanun } & 23 & $33,8 \%$ \\
\cline { 2 - 4 } & Perempuan & 45 & $63,2 \%$ \\
\hline \multirow{3}{*}{ Status IMT } & PNS bidan & 26 & $38,2 \%$ \\
\cline { 2 - 4 } & PNS perawat & 36 & $52,9 \%$ \\
\cline { 2 - 4 } & Honorer bidan & 4 & $5,9 \%$ \\
\cline { 2 - 4 } & Honorer perawat & 2 & $2,9 \%$ \\
\cline { 2 - 4 } & Overweight laki-laki & 13 & $19,1 \%$ \\
\hline & Overweight & 25 & $36,8 \%$ \\
\hline & Obempuan & 10 & $14,7 \%$ \\
\hline
\end{tabular}

\begin{tabular}{|c|c|c|c|}
\hline & Obesitas perempuan & 20 & $29,4 \%$ \\
\hline \multirow{2}{*}{$\begin{array}{l}\text { Tingkat } \\
\text { Risiko DM } \\
\text { tipe II }\end{array}$} & Rendah & 32 & $47,1 \%$ \\
\hline & Tinggi & 36 & $52,9 \%$ \\
\hline \multirow{2}{*}{$\begin{array}{l}\text { Riwayat } \\
\text { hipertensi }\end{array}$} & $\mathrm{Ya}$ & 22 & $32,4 \%$ \\
\hline & Tidak & 46 & $67,6 \%$ \\
\hline \multirow{2}{*}{$\begin{array}{l}\text { Riwayat } \\
\text { diabetes }\end{array}$} & $\mathrm{Ya}$ & 19 & $27,9 \%$ \\
\hline & Tidak & 49 & $72,1 \%$ \\
\hline \multirow{3}{*}{$\begin{array}{l}\text { Riwayat } \\
\text { keluarga } \\
\text { DM }\end{array}$} & Tidak ada & 34 & $50 \%$ \\
\hline & $\begin{array}{l}\text { Keluarga tidak } \\
\text { langsung }\end{array}$ & 18 & $26,5 \%$ \\
\hline & Keluarga langsung & 16 & $23,5 \%$ \\
\hline \multirow{2}{*}{$\begin{array}{l}\text { Kebiasaan } \\
\text { konsumsi } \\
\text { buah sayur }\end{array}$} & Setiap hari & 33 & $48,5 \%$ \\
\hline & Tidak setiap hari & 35 & $51,5 \%$ \\
\hline \multirow{2}{*}{$\begin{array}{l}\text { Aktivitas } \\
\text { fisik }\end{array}$} & $\mathrm{Ya}$ & 37 & $54,4 \%$ \\
\hline & Tidak & 31 & $45,6 \%$ \\
\hline \multirow{6}{*}{$\begin{array}{l}\text { Lingkar } \\
\text { perut }\end{array}$} & Laki-laki $<94$ & 5 & $7,4 \%$ \\
\hline & Laki-laki 94-102 & 13 & $19,1 \%$ \\
\hline & Laki-laki >102 & 7 & $10,3 \%$ \\
\hline & Perempuan $<80$ & 6 & $8,8 \%$ \\
\hline & Perempuan 80-88 & 23 & $33,8 \%$ \\
\hline & Perempuan $>88$ & 14 & $20,6 \%$ \\
\hline
\end{tabular}

Sumber : Data primer, 2019

\section{A. Usia}

Kelebihan berat badan adalah kondisi dimana berat badan lebih dari berat badan ideal atau normal. Kelebihan berat badan dibagi menjadi dua kelompok, yaitu obesitas dan overweight. Obesitas dapat terjadi pada segala umur, namun sering dianggap sebagai kelainan usia pertengahan. Dengan bertambahnya usia, kemampuan metabolik tubuh akan menurun sehinggan kebanyakan orang akan menyimpan kelebihan berat badan. Biasanya penimbunan lemak di perut dapat disebabkan karena stres (Riadi, 2016).

Trisnawati \& Setyorogo (2013) dalam penelitiannya menyatakan bahwa kelompok umur < 45 tahun memiliki resiko lebih rendah mengalami diabetes melitus dibandingkan dengan kelompok umur $>45$ tahun (Trisnawati \& Setyorogo, 2013).

Peningkatan resiko diabetes melitus pada umur $>40$ tahun disebabkan karena pada usia 40 tahun mulai terjadi peningkatan intoleransi glukosa sehingga menyebabkan menurunnya kemampuan sel beta pankreas untuk memproduksi hormon insulin (Riskesdas, 2013).

\section{B. Jenis Kelamin}

Obesitas maupun kelebihan berat badan dapat terjadi baik pada laki-laki maupun perempuan. Namun rata-rata perempuan memilki jumlah lemak 
yang lebih banyak daripada laki-laki. Selain itu, obesitas sering dijumpai pada perempuan setelah melahirkan maupun saat menopause. Hal ini mungkin disebabkan karena perubahan endokrin, karena pada saat-saat tersebut terjadi perubahan hormonal (Riadi, 2016).

Dalam penelitiannya Taylor, et al. (2010) menyatakan bahwa penyebab utama banyaknya perempuan terkena diabetes tipe 2 karena terjadinya penurunan hormon estrogen terutama saat masa menopause. Hormon estrogen dan progesteron memiliki kemampuan untuk meningkatkan respons insulin di dalam darah. Pada saat masa menopause terjadi, maka respons akan insulin menurun akibat hormon estrogen dan progesteron yang rendah. Faktor-faktor lain yang berpengaruh adalah body massa index perempuan yang sering tidak ideal sehingga hal ini dapat menurunkan sensitivitas respons insulin. Hal inilah yang membuat wanita sering terkena diabetes daripada laki-laki (Taylor, et al., 2010).

\section{Kelebihan berat badan berdasarkan IMT}

Adanya pengaruh IMT terhadap diabetes melitus disebabkan oleh kurangnya aktivitas fisik serta tingginya konsumsi karbohidrat, protein dan lemak yang merupakan factor risiko dari obesitas. Hal tersebut menyebabkan meningkatnya Asam Lemak atau Free Fatty Acid (FFA) dalam sel. Peningkatan FFA ini akan menurunkan translokasi transporter glukosa ke membrane plasma, dan menyebabkan terjadinya resistensi insulinpada jaringan otot dan adipose (Teixeria-Lemos, et al., 2011).

Penelitian yang dilakukan di Amerika Serikat pada 11.400 wanita menunjukkan bahwa wanita dengan IMT antara 22-26,9 $\mathrm{Kg} / \mathrm{m} 2$, berisiko menderita diabetes tipe II, delapan kali lebih besar dibandingkan wanita dengan IMT $<22 \mathrm{Kg} / \mathrm{m} 2$. Risiko ini meningkat 40 kali lebih besar dari pada wanita dengan IMT $>31 \mathrm{Kg} / \mathrm{m}^{2}$ (Witjaksono, 2004).

\section{Riwayat tekanan darah tinggi}

Penyakit hipertensi (tekanan darah tinggi) sangat berbahaya bagi kesehatan. Dengan tingginya kadar lemak dalam darah, sensitivitas darah terhadap insulin menjadi sangat rendah. Oleh karena itu, mereka yang menderita tekanan darah tinggi diharapkan mengkonsumsi makanan tinggi serat dan rendah lemak,seperti buah dan sayuran, sehingga mampu meningkatkan sensitivitas insulin. Jika sensitivitas insulin meningkat maka kontrol gula darah akan lebih baik dan kadar lemak dalam darah menjadi rendah. Rendahnya kadar lemak dalam darah akan menurunkan kemungkinan timbulnya komplikai penyakit jantung sehingga ikut menurunkan angka kematian pada penderita DM (Susilo, et al., 2011).

Penyebab resistensi insulin menjadi salah satu faktor risiko hipertensi adalah karena kondisi ini mengganggu metabolisme lemak serta meningkatkan kolesterol dan trigliserida. Pada akhirnya, resistensi insulin mengakibatkan peningkatan lemak tubuh dan obesitas. Penumpukan lemak dalam tubuh bisa mengganggu kerja sistem saraf, termasuk sinyal yang mengatur tekanan darah penyebab hipertensi. Efeknya bisa menyebabkan jantung bekerja lebih keras untuk memompa darah dan pengerutan pembuluh darah. Terlebih, resistensi insulin memicu ketidakseimbangan kadar garam dan kalium yang bisa meningkatkan volume darah serta kalsium dan magnesium yang menyebabkan penyempitan arteri. Itu mengapa resistensi insulin dapat menaikkan tekanan darah dan meningkatkan risiko penyakit jantung (Joseph \& Novita, 2018).

Penelitian Ichsantiarini (2013) menyatakan bahwa Keterkaitan kadar gula darah dengan tekanan darah akibat adanya kesamaan karakteristik faktor risiko penyakit. Resistensi insulin dan hyperinsulinemia diyakini dapat meningkatkan resistensi vascular perifer dan kotraktilitas otot polos vascular melalui respon berlebihan terhadap norefinefrin dan angiotensin II. Kondisi tersebut menyebabkan peningkatan tekanan darah maupun Sistem Renin-Angiotensin-Aldesteron (Ichsantiarini, 2013).

\section{E. Riwayat keluarga DM}

Setiap orang berpotensi mengidap DM, dari segala umur dan segala kalangan. Namun demikian, ada beberapa golongan yang sangat besar potensinya untuk terkena DM. Menurut urutan, golongan yang sangat berpotensi menderita DM adalah kedua orang tua menderita DM, salah satu atau saudara kandung 
menderita DM, atau salah satu atau keluarga menderita DM.

Hal ini sebanding dengan penelitian Nur Isnaini dan Ratna Sari yang berjudul faktor risiko mempengaruhi kejadian Diabetes melitus tipe dua. Ditemukan hasil bahwa faktor risiko yang terbukti berpengaruh dengan DM tipe dua di Puskesmas I Wangon adalah faktor genetik dengan keluarga, Orang dengan latar belakang keluarga yang memiliki satu atau lebih anggota keluarga dengan ibu, ayah ataupun keluarga yang terkena DM akan mempunyai peluang kejadian 2 sampai 6 kali lebih besar berpeluang terjadi diabetes dibandingkan dengan orang yang tidak memiliki keturunan penyakit DM. (Isnaini \& Ratnasari, 2018).

\section{F. Aktivitas fisik}

Kurangnya aktivitas fisik merupakan salah satu penyebab obesitas. Aktivitas fisik dapat mengontrol gula darah. Glukosa akan diubah menjadi energi pada saat beraktivitas fisik. Aktivitas fisik mengakibatkan insulin semakin meningkat sehingga kadar gula dalam darah akan berkurang. Pada orang yang jarang berolahraga, zat makanan yang masuk ke dalam tubuh tidak dibakar tetapi ditimbun dalam tubuh sebagai lemak dan gula sehingga menyebabkan kegemukan. Jika insulin tidak mencukupi untuk mengubah glukosa menjadi energi maka akan timbul DM (Kemenkes, 2017).

Menurut Riset Kesehatan Dasar (2013), persentase penduduk Indonesia dengan faktor resiko diabetes melitus berdasarkan aktifitas fisik yang kurang sebanyak $26,1 \%$ pada populasi 10 tahun keatas. Hasdianah (2012) orang yang malas untuk melakukan olahraga akan meningkatkan resiko terjadinya diabetes melitus karena meningkatnya kaloriyang tertimbun dalam tubuh akan menyebabkan disfungsi pankreas (Riskesdas, 2013).

\section{G. Riwayat diabetes}

Untuk kebanyakan individu, DM tipe II berkaitan dengan kegemukan. Selain itu, kecenderungan pengaruh genetik, yang menentukan kemungkinan individu mengidap penyakit ini, cukup kuat. Diperkirakan bahwa terdapat sifat genetik yang belum teridentifikasi yang menyebabkan pankreas mengeluarkan insulin yang berbeda, atau menyebabkan reseptor insulin atau perantara kedua tidak dapat berespon secara adekuat terhadap insulin. Terdapat kemungkinan lain bahwa kaitan rangkai genetik antara yang dihubungkan dengan kegemukan dengan rangsangan berkepanjangan reseptor-reseptor insulin. Rangsangan berkepanjangan atas reseptorreseptor tersebut dapat menyebabkan penurunan jumlah reseptor insulin yang terdapat disel tubuh. Penurunan ini disebut down regulation (Corwin, et al., 2009).

Pada stadium prediabetes mula-mula timbul resistensi insulin yang kemudian disusul oleh peningkatan sekresi insulin untuk mengkompensasi resistensi insulin itu agar kadar glukosa darah tetap normal. Lama-kelamaan sel $\beta$ akan tidak sanggup lagi mengkompensasi resistensi insulin sehingga kadar glukosa darah meningkat dan fungsi sel $\beta$ pankreas makin menurun saat itulah diagnosis diabetes ditegakkan (Soegondo, et al., 2009).

\section{H. Konsumsi buah dan sayur}

Hasil penelitian riset kesehatan dasar (Riskesdas, 2010) menyatakan masih banyak penduduk yang tidak cukup mengonsumsi sayuran dan buah-buahan. Data (Riskesdas, 2013) menyebutkan sebanyak $93,5 \%$ penduduk usia $>10$ tahun mengkonsumsi sayuran dan buah-buahan di bawah anjuran. Padahal, konsumsi sayuran dan buahbuahan merupakan salah satu bagian penting dalam mewujudkan gizi seimbang.

Sayuran dan buah-buahan merupakan sumber berbagai vitamin, mineral, dan serat pangan. Sebagian vitamin, mineral yang terkandung dalam sayuran dan buah-buahan berperan sebagai antioksidan atau penangkal senyawa jahat dalam tubuh. Berbeda dengan sayuran, buah-buahan juga menyediakan karbohidrat terutama berupa fruktosa dan glukosa. Berbagai kajian menunjukkan bahwa konsumsi sayuran dan buah-buahan yang cukup turut berperan dalam menjaga kenormalan tekanan darah, kadar gula dan kolesterol darah (Riskesdas, 2010).

\section{Lingkar perut}

Menurut Damayanti (2010), penyebab bertambahnya lingkar perut atau pinggang ini bias berbagai macam, diantaranya yang pertama gaya hidup, pola makan yang tidak benar dan kebiasaan 
hidup yang kurang aktivitas, konsumsi makanan yang berlebih dari energi yang dibutuhkan. Kedua, usia akan aktivitas yang kurang tidak diimbangi dengan mengurangi asupan kalori berat, semakin bertambah usia semakin bertambah lingkar perut/pinggang. Ketiga faktor genetik, orang dapat berkecenderungan menumpuk lemak diperut secara genetik (Damayanti, 2010).

Hasil penelitian ini sesui dengan teori bahwa lemak diperut adalah lemak paling berbahaya. Lemak yang berada diperut dibagian dalam akan mengeluarkan asam lemak bebas dan puluhan hormone yang dapat menimbulkan berbagai masalah. Jaringan lemak yang merupakan tempa deposit kelebihan kalori, terutama dibagian dalam rongga perut dapat mengganggu kerja insulin (resistensi insulin) (Darmoutomo, 2005 dalam Arisman, 2010).

TABEL 2. Hubungan Kelebihan Berat Badan dengan Tingkat Risiko DM Tipe II pada Mahasiswa Kelas Program Khusus Poltekkes Palangkaraya

\begin{tabular}{|c|c|c|c|c|}
\hline $\begin{array}{c}\text { Kelebihan } \\
\text { berat badan } \\
\text { berdasarkan } \\
\text { IMT }\end{array}$ & Rendah & Tinggi & $\begin{array}{c}\text { OR } \\
\text { (Odds } \\
\text { Ratio) }\end{array}$ & $\begin{array}{c}\text { P- } \\
\text { value }\end{array}$ \\
\hline $\begin{array}{l}\text { Berat badan } \\
\text { lebih }\end{array}$ & $\begin{array}{c}22 \\
(57,9 \%) \\
\end{array}$ & $\begin{array}{c}16 \\
(42,1 \%) \\
\end{array}$ & \multirow{3}{*}{2,750} & \multirow{3}{*}{0,077} \\
\hline Obesitas & $\begin{array}{c}10 \\
(33,3 \%)\end{array}$ & $\begin{array}{c}20 \\
(66,7 \%)\end{array}$ & & \\
\hline Total & $\begin{array}{c}32 \\
(41,1 \%) \\
\end{array}$ & $\begin{array}{c}36 \\
(52,9 \%) \\
\end{array}$ & & \\
\hline
\end{tabular}

Berdasarkan tabel 2 data tersebut dianalisa menggunakan uji chi-square, didapatkan hasil pvalue $=0,077$ artinya terdapat hubungan antara kelebihan berat badan terhadap tingkat risiko DM tipe II pada mahasiswa kelas program khusus Poltekkes Palangkaraya, hal tersebut menunjukkan bahwa Ha diterima dan Ho ditolak. Nilai OR (Odds Ratio) $=2,750$, menunjukkan bahwa responden dengan BB kategori obesitas berisiko atau berpotensi 2.750 kali untuk terkenan DM tipe II dibandingkan dengan responden yang masuk dalam kategori BB lebih.

Berdasarkan hasil penelitian menunjukkan bahwa dari 68 responden didapat 22 respoden dengan BB lebih memiliki tingkat risiko DM tipe II dalam kategori rendah dengan presentase sejumlah 57,9\%. Sedangkan untuk responden dengan BB lebih yang memiliki tingkat risiko DM tipe II dalam kategori tinggi sebanyak 16 orang dengan presentase sejumlah
42,1 \%. Selain itu juga didapat responden dengan obes yang memiliki tingkat risiko DM tipe II dalam kategori rendah sebanyak 10 orang dan presentasenya sejumlah 33,3\%. Kemudian untuk responden dengan obes yang memiliki tingkat risiko DM tipe II dalam kategori tinggi sebanyak 20 orang dan presentasenya sejumlah 66,7 \%. Data tersebut dianalisis menggunakan uji chi-square, didapatkan nilai $\mathrm{p}$ value $=0,077$ artinya ada hubungan antara kelebihan berat badan berdasarkan indeks massa tubuh terhadap tingkat risiko DM tipe II. Hal ini sejalan dengan penelitian sebelumnya yang dilakukan oleh Fathurohman (2015) yang menyatakan bahwa terdapat hubungan antara IMT dengan tingkat risiko DM tipe II.

Mekanisme yang mendasari lebih tingginya risiko DM tipe II pada individu dengan obesitas adalah karena pada keadaan obesitas terjadi peningkatan asam lemak, penumpukan lipid intra sel, dan pembentukan sitokin oleh adiposity yang menyebabkan kerusakan fungsi insulin. Pada keadaan obesitas juga terjadi proses inflamasi akibat peningkatan sitokin proinflamasi dan infiltrasi makrofag disertai adanya induksi respon stres yang dapat menyebabkan resistensi insulin.

Hasil penelitian lain juga membuktikan bahwa ada hubungan yang erat obesitas abdominal dan faktor risiko penyakit kardiovaskuler yaitu diabetes melllitus, hipertensi dan dislipidemia. Massa lemak tidak hanya tempat penyimpanan energi, tetapi juga sebagai jaringan dinamis dengan berbagai fungsi. Kelebihan massa lemak juga dikaitkan dengan keadaan resistensi insulin yang berhubungan dengan diabetes mellitus. Risiko diabetes melitus akan meningkat secara linear sesuai dengan peningkatan IMT. Overweight akan meningkatkan angka kejadian diabetes melitus 3-4 kali dibandingkan orang dengan IMT normal (Pratiwi, 2010).

Bagi mereka yang mengalami kegemukan di sekitar perut (abdominally obese), salah satu mekanisme yang diduga menjadi predisposisi DM tipe II adalah terjadinya pelepasan asam-asam lemak bebas secara tepat, yang berasal dari suatu lemak yang membesar. Proses ini menerangkan terjadinya sirkulasi tingkat tinggi dari asam-asam lemak bebas dihati sehingga kemampuan hati untuk mengikat dan 
mengekstrak insulin dari darah menjadi berkurang. Hal ini mengakibatkan hiperinsulinemia. Akibat lainnya adalah peningkatan glukoneogenesis (glukosa darah meningkat) (Susilo, et al., 2011).

\section{KESIMPULAN}

Faktor risiko yang dapat dilihat dari penyebab DM (Diabetes Mellitus) diantaranya yaitu usia, riwayat tekanan darah tinggi, riwayat gula darah tinggi, riwayat keluarga dengan DM, kebiasaan konsumsi buah dan sayur, kebiasaan aktivitas fisik sehari-hari, indeks massa tubuh, lingkar perut.

Berdasarkan hasil penelitian menunjukkan bahwa dari 68 responden didapat 22 respoden dengan BB lebih memiliki tingkat risiko DM tipe II dalam kategori rendah dengan presentase sejumlah 57,9\%. Sedangkan untuk responden dengan BB lebih yang memiliki tingkat risiko DM tipe II dalam kategori tinggi sebanyak 16 orang dengan presentase sejumlah $42,1 \%$. Selain itu juga didapat responden dengan obesitas yang memiliki tingkat risiko DM tipe II dalam kategori rendah sebanyak 10 orang dan presentasenya sejumlah 33,3 \%. Kemudian untuk responden dengan obes yang memiliki tingkat risiko DM tipe II dalam kategori tinggi sebanyak 20 orang dan presentasenya sejumlah $66,7 \%$.

\section{DAFTAR PUSTAKA}

Arisman. 2010. Buku Ajar Ilmu Gizi. Jakarta : EGC.

Badan Penelitian dan Pengembangan Kesehatan. 2010. Riset Kesehatan Dasar 2010. Kementerian Kesehatan RI.

Badan Penelitian dan Pengembangan Kesehatan. 2013. Riset Kesehatan Dasar 2013. Kementerian Kesehatan RI.

Corwin J. E. 2009. Buku Saku Patofisiologi Edisi 3. Jakarta : EGC.

Damayanti, L. 2010. Penyebab Perut Buncit Dalam http://kesehatan kompas.com, Diakses tanggal 15 mei 2019.

Diabetes UK. 2010. Diabetes in the UK 2010: Key Statistics on Diabetes.
Fathurohman, I. 2015. Penilaian tingkat risiko dan faktor-faktor yang berhubungan dengan risiko diabetes melitus tipe 2 pada masyarakat binaan kpkm buaran pada tahun 2015. Skripsi. Universitas Islam Negeri Syarif Hidayatullah, Jakarta.

Ichsantiarini, A.P. 2013. Hubungan Diabetes melitus Tipe 2 Dengan Kendali Tekanan Darah Pada Pasien Hipertensi Rumah Sakit Dr. Sucipto Mangunkusomo. Skripsi. Universitas Indonesia, Jakarta.

Internasional Diabetes Federation (internet). (Place Unknown): Internasional Diabetes Federation. Diabetes Questionnaire; (online) http://www.iff.org/webdata/docs/FINDRISC_E nglish.pdf diakses pada 10 januari 2019

Isnaini, N, \& Ratnasari. 2018. Faktor risiko mempengaruhi kejadian diabetes melitus tipe dua. Jurnal Kebidanan dan Keperawatan Aisyiyah. 14(1):59-68.

Joseph \& Novita. 2018. Bagaimana Resistensi Insulin Dapat Menyebabkan Tekanan Darah Tinggi. (online) https://hellosehat.com/pusatkesehatan/hipertensi-tekanan-darahtinggi/hubungan-diabetes-dan-hipertensi/, diakses pada 19 mei 2019.

Kementerian Kesehatan Republik Indonesia. 2017. Pusat Data dan Informasi Profil Kesehatan Indonesia 2017.

Lemeshow, S., David, W. H., Janelle, K., \& Stephen, K. L. 1997. Besar Sampel Dalam Penelitian Kesehatan. Terjemahan Dibyo Pramono. Yogyakarta, Gadjah Mada University Press.

Pratiwi, Y. S. 2010. Diabetes melitus pada obesitas. The Indonesian Journal Of Health Science. 1(1):61-70.

Riadi, M. 2016. Pengertian Penyebab dan Faktor Risiko Obesitas. Dikutip dari : (https://www.kajianpustaka.com/2016/01/penge rtian-jenis-faktor-penyebab-obesitas.html) diakses pada selasa 5 februari 2019.

Soegondo. 2009. Penatalaksanaan Diabetes Melitus Terpadu: Buku Ajar Ilmu Penyakit Dalam, Edisi 4. Jilid 3. Jakarta: FKUI. 
BJMLT

Soegondo, S., Soewondo, P., \& Subekti I. 2009. Penatalaksanaan Diabetes melitus Terpadu. Jakarta : FKUI.

Susilo, Y., \& Wulandari, A. 2011. Cara Jitu Mengatasi Kencing Manis (Diabetes Mellitus).Yogyakarta : $\quad$ CV ANDI OFSET(ANDI)

Taylor, C., Lilis, C., LeMone, P., Lynn, P. 2010. Fundamental of nursing: The Art and Science of Nursing Care, Ed. 7th. Philadelphia: Lippincott Williams \& Wilkins.

Teixeria-Lemos, et al. 2011. Regular physical exercise training assists in preventing type 2 diabetes development: focus on its antioxidant and anti-inflammantory properties. Biomed Central Cardiovascular Diabetology.10:1-15.

Trisnawati, S.K., \& Setyorogo.S. 2013. Faktor risiko kejadian diabetes melitus tipe II di Puskesmas Kecamatan Cengkareng Jakarta Barat Tahun 2012. Jurnal Ilmiah Kesehatan. 5(1):6-11.

Wahyu, G. G. 2009. Obesitas Pada Anak. Jakarta : Bentang Pustaka.

Witjaksono, F. 2004. Obesitas Bukan Lagi Tanda Kemakmuran. Indonesian Society For The Study Of Obesity (ISSO/Himpunan Obesitas Indonesia

(HISOBI). www.google.co.id/obesitas. diakses pada 8 februari 2019 . 